\title{
Theatrum internum - theatrum mundi
} Om fantasi og litteratur

Om sin meget begavede patient, hysterikeren Anna O (Bertha Pappenheim), der endte med at blive hædret med et frimærke af Forbundsrepublikken, beretter Josef Breuer:

»Denne med en overflod af åndelig vitalitet begavede pige førte i den puritansk sindede familie et højst monotont liv, som hun forsk $\varnothing n$ nede på en for sin sygdom øjensynligt karakteristisk måde. Hun dyrkede systematisk dagdrømmen, som hun kaldte sit »privatteater«. Medens alle troede hende tilstedeværende, oplevede hun i sin bevidsthed [im Geiste] eventyr; men hun var, når hun blev tiltalt, altid præsent, og derfor anede ingen derom. Ved siden af udførelsen af de huslige gøremål, som hun altid bes $\varnothing$ rgede udadleligt, fortsatte denne åndelige aktivitet næsten uden afbrydelse.« (Freud /Breuer 1970 (1895):20, min oversættelse).

Efterhånden som hun blev mere syg, blev hendes absencer mere påfaldende og for hende selv pinefulde. Lod man imidlertid et stikord falde, begyndte hun, først brudstykkeagtigt, men efterhånden mere og mere flydende at udmale sin pinefulde situation eller at fortælle historier. Om disse historier skriver Breuer:

»Historierne, altid sørgelige, var for en dels vedkommende meget smukke efter maner af Andersens Billedbog uden Billeder, og sandsynligvis også dannet med denne som mønster. For det meste var udgangs- eller midtpunktet for situationen en ung pige, der angstfuldt sad ved en syg;... Et $\varnothing j$ jeblik efter afslutningen af historien vågnede hun og var åbenbart beroliget.« (Freud/Breuer 1970:26)

De historier, Anna $O$ på dette tidspunkt af sin sygdom fortæller under søvntilstanden, har således et dobbelt udspring, dels hendes konkrete situation, hun plejer sin døende fader og sidder næsten uafbrudt ved hans sygeleje, dels et litterært forbillede, der tjener som model for hendes egen produktion af dag-

$K \& K 72$ (1992), 11-37 
drømme, og af historier, der fortælles til andre. Endvidere ses det, at ifølge Breuer har selve italesættelsen og kommunikationen af fantasierne, selv om det sker i en søvnlignende tilstand, en terapeutisk effekt.

Da faderen dør, bliver hendes historier endnu mere sørgelige, og som hendes sygdom forværres, opløses den narrative struktur i hendes fantasier og de forvandles til frygtelige og angstfyldte hallucinationer. Imidlertid lader Breuer hende fortælle om disse og: "efter at hun rystet af angst og gru havde reproduceret og udtalt alle disse skrækbilleder, var hendes sind fuldstændig befriet « (ibid. 27). I den øvrige terapi følger Breuer samme teknik. Han forfølger ethvert symptoms historie baglæns til dets første forekomst, og når Anna $O$ har sat ord på dets historie, så synes det at forsvinde.

$\mathrm{Nu}$ ved vi, at Anna O's sygehistorie faktisk var mere kompliceret end Breuer lader formode i Studien über Hysterie, og vi må formode, at Breuer ikke nåede særlig langt i sin forståelse af sygdommens ætiologi eller måske snarere har udeladt vigtige forhold i sygehistorien. Vi ved også, at bedringen ganske vist fandt sted, men senere (som Breuer loyalt refererer) og efter at hun var blevet yderligere behandlet på et hospital i Schweiz (cf. Jones 1953,1: 22326 og Gay 1988: 63-69). I vor sammenhæng er det vigtige dog nogle spørgsmål i forbindelse med hendes fantasier. Lad os en sidste gang lytte til Breuers ætiologiske udredninger:

Hos den endnu fuldstændig raske pige finder vi to ejendommeligheder, som disponerer for den hysteriske lidelse:

»1) Det i det monotone familieliv og uden en til det passende åndelig aktivitet ubenyttede overskud af psykisk bevægelighed og energi, der udlades $i$ et stadigt foregående fantasiarbejde, og som

2) skaber den vanemæssige dagdrømmen [privatteatret], hvorved grunden bliver lagt til en spaltning af sindet [der geistlichen Persönlichkeit]. Når alt kommer til alt, forbliver også denne spaltning inden for det normales grænser; såvel drømmerier som meditation under et mere eller mindre mekanisk arbejder betinger i sig selv ingen patologisk bevidsthedsspaltning, fordi enhver forstyrrelse af dem, f.eks. ethvert tilråb, genetablerer dens enhed, og fordi der vel heller ikke opstår nogen amnesi. Dog hos Anna $\mathrm{O}$ blev herigennem det grundlag skabt, på hvilket angstog forventningsaffekten satte sig fast på den skildrede måde, efter at den havde omskabt det vanemæssige drømmeri til en hallucinatorisk absence.«(Freud/Breuer 1970:36)

Breuer blev ikke selv psykoanalytiker, og i hans og Freuds fælles afhandling, Studien über Hysterie, kommer deres forskellige opfattelse af hysterien til ud- 
tryk. Imidlertid anslås allerede i Anna O's sygehistorie en rakke temaer og problemer, der optager den psykoanalytiske diskussion af fantasibegrebet:

1) Fantasiaktivitetens udspring, herunder

2) spørgsmålet om dens energetiske grundlag.

3) Forholdet mellem krop og psyke.

4) Forholdet mellem normalitet og patologi i fantasiaktiviteten.

5) Forskellen mellem fantaseren og hallucineren.

6) Spørgsmålet om psykens spaltning og fantasiens tilhørsforhold til dens forskellige provinser eller tilstande.

7) Italesættelsens terapeutiske effekt, hvadenten det drejer sig om fantasier eller mere regelrette symptomer.

Hertil kommer de spørgsmål, der særligt interesserer i vor sammenhæng, nemlig:

8) Forholdet mellem fantasi og litteratur: den førstes rolle i produktionen af den sidste, og

9) de forhold og processer der nødvendigvis må intervenere, for at fantasier kan blive til litteratur, altså overgangen og forskellen mellem privatteatret og verdensteatret.

\section{Subjekt, omverden og fantasi}

På næsten samme tid som samarbejdet med Breuer fandt sted, var Freud selv optaget af at konstruere en almen model for psyken og de psykiske processer, et konstruktionsarbejde hvis første højdepunkt er Entwurf einer Psychologie (1895, der endte i skrivebordsskuffen, men blev udgivet i 1950), og hvis andet højdepunkt er kapitel 7 af Die Traumdeutung (1900). I disse to skrifter giver Freud også et bud på en besvarelse af de ovenfor anførte spørgsmål.

Freuds Entwurf... er et storstilet forsøg på en materialistisk fundering af psykologien i neurologien og biologien. Han forestiller sig, at udviklingen af psykisk aktivitet foregår som en prægning af neuronerne gennem ydre og indre stimuli og i kraft af baninger mellem dem. Prægninger og baninger bliver anset for hukommelsens eller erindringens neurologiske fundament. $\mathrm{Og}$ erindringen og dens forhold til perceptionen spiller en afgørende rolle for den psykoanalytiske forståelse af hallucination og fantasi.

Det helt unge barn er udleveret til sanseindtryk, hvadenten de stammer fra kroppens indre eller fra dets kontakt med omverdenen. Disse opdeles i lyst- og 
ulystvækkende, ligesom overgangen mellem lysttilstand og ulysttilstand registreres. Begge tilstande og overgangen dem imellem præges ifølge Freud i psyken som erindringsbilleder, eller rettere sagt som to konglomerater af forskellige sanseindtryk (ordet billede er vildledende, da ikke kun synet er impliceret), der associeres under sansningen og i erindringen. Lyst og ulyst er de psykiske udtryk for tilfredsstillelse eller frustrering af legemsbehov eller ved givne legemlige tilstande. Psyken registrerer således både en kropslig mangeleller fyldetilstand og den handling (specifikke aktion), der forårsager overgangen fra den ene til den anden. Når de legemlige behov atter melder sig som trang i psyken, besættes disse erindringsforestillinger med energi, ligesom fremkomsten af impulser eller sanseindtryk, der tidligere har været forbundet med ulyst og smerte, associeres med erindringer herom. Herved etableres to grundlæggende psykiske processer: den primare ønsketiltrakning (primäre Wunschanziehung) og det primære forsvar (primäre Abwehr, også Verdrängung), der af Freud beskrives som henholdsvis en energitilstrømning til erindringerne (el. hukommelsessporene) og en tømning af dem for energibesætning.

Freud forestiller sig nu, at denne enkle model for psyken (bygget over refleksapparatet) hos det helt unge barn konkret fungerer som følger, når barnet oplever en mangeltilstand på grund af uopfyldte behov:

Den af det indre behov fremkaldte excitation vil søge afløb i motiliteten, som man kan betegne som »indre forandring « eller som »udtryk for sindsbevægelse«. Det sultne barn skriger eller spræller hjælpeløst. Men situationen forbliver uforandret, thi den fra det indre behov udgående excitation er ikke en momentan, men en kontinuerligt virkende kraft. En forandring kan først ske, når der på en eller anden måde (for barnet ved fremmed hjælp) erfares en tilfredstillelsesoplevelse, der ophæver den indre stimulus. En væsentlig bestanddel af denne oplevelse er, at der opstår en vis perception (næringen i eksemplet), hvis erindringsbillede fra nu af forbliver associeret med hukommelsessporet af den excitation, behovet fremkaldte. Så snart dette behov optræder næste gang, vil der, takket være den etablerede tilknytning, resultere en psykisk impuls, som vil søge atter at besætte erindringsbilledet af denne perception og atter at fremkalde selve denne, altså i grunden retablere den første tilfredsstillelsessituation. En sådan impuls er det, vi kalder for et ønske; perceptionens genoptræden er ønskeopfyldelsen, og den fulde besætning af perceptionen er den korteste vej fra behovets fremkaldelse til ønskeopfyldelsen. Intet hindrer os $i$ at antage, at der fandtes en primitiv tilstand af det psykiske apparat, i hvilken denne vej virkelig fulgtes på denne måde og ønsket således endte i en hallucination. Denne første psykiske virksomhed sigtede altså på en perceptionsidentitet, nemlig på gentagelsen af den perception, der er forbundet 
med tilfredsstillelsen af behovet. (Freud 1960:П1, 444-45)

Den korteste vej mellem ønske og opfyldelse er således fremkaldelsen af et erindringsbillede (af en tidligere eller forestillet tilfredsstillelsessituation), således at det fremstår som en perception. Da imidlertid intet i yderverdenen svarer dertil, er perceptionsidentiteten hallucinatorisk. Erfaringen, livets nød og den psykiske udvikling og modning lærer subjektet at skelne mellem perception og forestilling gennem den såkaldte realitetsprøve; men den hallucinationsagtige fantasivirksomhed fortsætter i drømmene og i dagdrømmene.

Hermed har Freud også givet visse retningslinier for besvarelsen af nogle af de spørgsmål, som Anna O's analyse gav anledning til: Fantasi både er og ikke er en originær psykisk aktivitet. Selv om den hviler på perceptionen af ydre og indre stimuli, er det meningsløst at se den som en tilkommet eller senere udviklet psykisk aktivitet, fordi den, ifølge psykoanalysen, fungerer fra først af. På dette tidlige tidspunkt er skellet fantasi vs perception, fantasi vs virkelighed og hallucination vs fantasi imidlertid endnu ikke etableret. Man kan vælge på dette tidspunkt i barnets udvikling at betragte den psykiske aktivitet som et udifferentieret konglomerat af perceptioner og hallucinationer, der i stedet er opdelt i forhold til modsætningen mellem lyst og ulyst. Tager man dette udgangspunkt, kan vigtige dele af den psykiske udvikling fremstilles som differentieringer i kraft af nogle modsætninger, der etablerer en mere kompleks selv- og omverdensforståelse i subjektet. Ja, modsætninger i kraft af hvilke subjekt-omverdenskategorierne først selv etableres.

Udgangspunktet er egenkroppen, og de fundamentale modsætninger, der efterhånden bliver operative er her vs der, og når kroppens overflade opfattes som grænse, indre vs ydre. Ligeledes med kropstilstanden som udgangspunkt, modsætningen $n u$ vs $f ø r$, uden hvilken erindring og perception ikke kan skelnes. Et tredie moment i tidens kategorisering bliver så fremtidens herefter, hvorved forventning og frygt muliggøres. Etableringen af modsætningen mellem del og helhed og underordningen af den første under den sidste er ligeledes et vigtigt aspekt af jeg'ets og objektets konstituering i psyken. $\mathrm{Og}$ således også modsætningen og sammenhængen mellem årsag og virkning, der muligør forudsigelse og instrumentel handlen. Freud antager, at etableringen af forestillingerne om rum, tid og årsag sker gennem læreprocesser (e.g. gennem mangeloplevelser og skuffelser) $\mathrm{i}$ interaktionen med den plejende person, den specifikke anden, og på grundlag af de enkle psykiske primærprocesser, ifølge hvilke forestillinger associeres ud fra lighed og narhed. Endelig differentieres psyken selv ud fra modsatningen bevidst vs ubevidst.

Etableringen af dette skel rummer et problem: for $i$ en vis forstand implicerer Freuds model for psyken, at ubevidste psykiske processer foregår fra først af, da bevidsthed for Freud er en kvalitet, der karakteriserer en forsvindende 
lille del af den psykiske aktivitet. Derfor er ubevidst psykiske processer i deskriptiv forstand primare. I dynamisk forstand sker der imidlertid en differentiering af det ubevidste og det bevidste, da det dynamisk ubevidste antages at bestå af stærkt driftsbesatte forestillinger, der enten aldrig har været bevidste (cf. den såkaldte urfortrangning) eller er blevet fortrængt fra det bevidste og førbevidste. Disse forestillinger er særdeles aktive og søger at trænge frem til bevidstheden. De stoppes imidlertid af censuren og bliver kun bevidste i forvrænget form eller under visse psykiske tilstande, drømmesøvnen, visse psykiske lidelser - og i den psykoanalytiske dialog.

Først i forhold til ovennævnte modsætninger kan man forsøge at indkredse fantasibegrebet. Den delvist bevidst producerede fantasi, f.eks. en dagdrøm, er et antal indbyrdes forbundne forestillinger, der oftest danner tableauer eller episoder, der endog kan knyttes sammen til mere eller mindre udbyggede fortællinger. Benæunelser af et sådant fænomen som privatteater eller indre biograf er velvalgte, fordi tableauerne oprulles for dagdrømmerens indre syn; men alligevel er der afgørende forskelle. I teatret eller biografen perciperer man ydre stimuli, personerne på scenen eller lærredets billeder. Oplevelsens ydre kilde gør det meningsfuldt at tale om gyldighed og ugyldighed i subjektets opfattelse af det fremstillede; for det er en intersubjektiv realitet. I dagdrømmen er subjektet tilskuer til sine egne forestillinger, og såfremt der ikke er tale om hallucinationer, besidder disse ingen realitetstegn for ham. Og selv en tvangsmæssig dagdrømmer kan redigere i sine drømme, »spole filmen tilbage«, og »tage scenerne om«, hvis de ikke opfylder hans krav eller - lyst (cf. nedenfor). Faktisk er dagdrømmeren mere lig en instruktør i marken og ved klippebordet end en tilskuer.

Anskuet i forhold til uddifferentieringen af selv- og omverdensforståelsen har dagdrømmien en tvetydig status. For selv om dens iscenesættelser af erindrings- og fantasielementer naturligvis ikke er realitetsbunden, men tværtimod udspiller sig på en indre scene, så er der, i hvert fald delvist (cf. nedenfor), tale om en domesticeret psykisk aktivitet, hvis irreelle, imaginære natur subjektet er velvidende om (cf, at da Anna $O$ blot dagdrømte, adskilte hun meget vel denne aktivitet fra den omgivne virkelighed). Men i modsatning til fantasiudfoldelse i leg, hvor det imaginære rum podes på det fysiske og sociale rum (en skikkelig dansk skov bliver Amazonas jungle) og deles med andre, er dagdrømmen et privat fænomen, som andre ikke har del i og kun kender gennem rapporter, verbalisering og billedgørelse. Alligevel er den et kommunikativt fænomen, omend autokommunikativt, for den indebærer, at den dagdrømmende spaltes i tilskuer og handling. En handling hvor subjektet også vil være til stede, både $\mathrm{i}$ en eller anden konkret rolle og ved at have del $\mathrm{i}$ dem alle. Men hvilket formål har denne autokommunikation? Den synes at være formålslø- 
se iscenesættelser af driftsbesatte forestillinger, der giver det drømmende subjekt stærk lystfølelse og synes eksistentielt relevante for ham, uden at lysten og relevansen altid umiddelbart kan begrundes.

Denne dagdrømmens gådefuldhed peger på fantasiens dobbelte placering $\mathrm{i}$ psyken, både i det dynamisk ubevidste og i det førbevidste og på, at den er indskrevet i subjektets genese og historie. Freud beskriver fantasiernes særlige status således:

"Blandt $u b v$-driftsimpulsernes derivater af den beskrevne karakter findes der nogle, som forener modsatte bestemmelser i sig. De er på den ene side højt organiserede, modsigelsesfrie og har udnyttet alle de egenskaber, som systemet $b v$ har erhvervet sig. Ud fra vor vurdering kan de vanskeligt adskilles fra dette systems dannelser. På den anden side er de ubevidste og ude af stand til at blive bevidste. De hører altså kvalitativt til systemet $f b v$, men rent faktisk til $u b v$. Deres oprindelse bliver afgørende for deres skæbne. Man kan sammenligne dem med de raceblandede individer, der i det store og hele ligner de hvide, men som forråder deres nedstamning fra de farvede ved et eller andet påfaldende træk og af den grund bliver holdt ude fra samfundet uden at kunne nyde nogen af de hvides forrettigheder. Af en sådan slags er både de normales og neurotikernes fantasidannelser, som vi har erkendt som forstadier til både drømme- og symptomdannelsen, og som trods deres høje organisation vedbliver med at være fortrængte og dermed ude af stand til at blive bevidste. De kommer helt frem til bevidstheden og forbliver uforstyrrede, så længe de ikke har nogen intens besætning, men de bliver kastet tilbage, så snart de overskrider en vis grad af besætning." (Freud 1983 (1915e): 186-87)

Fantasierne kan således opnå en delvis, men ændret fremtræden i bevidstheden, såfremt denne fremtræden ikke aktiverer forbindelserne til elementer, der er fortrængt. En intens besætning af dem truer imidlertid med en aktivering af ubevidste elementer, og derfor fortrænges hele tableauet momentant. Den tætte sammenhæng mellem ubevidste fantasier og bevidste, som f.eks. dagdrømmen, understreges også af Laplanche og Pontalis: „Således synes drømmens to yderpunkter og fantasiens [fr. fantasme] to modaliteter som mødes dér, om ikke at forenes, så i det mindste at kommunikere med hinanden indefra og gensidigt at symbolisere hinanden. (Laplanche et Pontalis 1964:1859) 


\section{Lysten, kroppen og objektet}

De primitive psykiske mekanismer, der ligger til grund for fantasilivet er ifølge Freud enten ønskeimpulsens fors $\emptyset \mathrm{g}$ på at etablere en hallucinatorisk perceptionsidentitet med en tidligere tilfredsstillelsesoplevelse eller det primære forsvars sammenbrud, hvorved angstladede forestillinger overvælder psyken med hallucinatorisk styrke. Og de er begge knyttet til oplevelser og erindringer af kropslig art henholdsvis mangel og fylde, spænding og udladning.

Fantasierne er således knyttet til kroppens historie. Dog uden den andens tilstedeværelse ville denne historie blive ganske kort, da det hjælpeløse spædbarn og også det unge barn ville omkomme. Endvidere mestrer spædbarnet hverken skellet mellem del og helhed eller egenkrop og objekt. Det eksisterer i et såkaldt symbiotisk forhold til moderen (den plejende person); og de dele af egenkrop og objekt, der er kilde til lyst og ulyst, bliver bestemmende for fantasiaktiviteten. Freuds fremstilling af den psykoseksuelle udvikling i Drei Abhandlungen zur Sexualtheorie (1905d og flere senere udvidede udg.) bliver grundlæggende også for den psykoanalytiske forståelse af fantasien. Ud over faseinddelingen (cf. nedenfor) er det vigtigt, at Freud her ser den seksuelle lyst knyttet til og modelleret over tilfredsstillelsen og frustreringen af de legemsbehov, der må opfyldes for at livet kan opretholdes: fødeindtagelse, udskilllelse af affaldsstoffer, skærmelse mod kulde og varme, mod fald, slag, stød, kvælning, etc. og den pleje der sikrer kropsligt velvære og psykisk tryghed, hygiejne, omsorg og kommunikation. Kropslysten har således mange kilder; men ifølge Freud bliver tilfredsstillelsens lyst, selv om den har en specifik kilde, oplevet dobbelt af barnet, både som en tilfredsstillelse af et specifikt behov og som en erotisering, dels og stærkest af de involverede kropsdele, dels globalt som en erotisering af kroppen. Heraf den såkaldte autoerotik, hvor hele kroppen kan fungere som lystobjekt, men hvor de forskellige partialdrifter primært tilfredsstilles ved de kropszoner, hvortil de er knyttet, gennem oplevelsen af den såkaldte organlyst. Denne sidste skelnes fra den lyst, der er knyttet til organernes funktion i tilfredsstillelsen af vitale behov. Spædbarnets dien tilfredsstiller et vitalt behov; men spædbarnets sutten, på narresut eller tommelfinger, er selvstændiggjort fra opfyldelsen af fødebehovet og giver således en selvstændiggjort tilfredsstillelse: organlyst.

Psykoanalysens sammenknytning af fantasiaktiviteten med (gen)oplevelsen af elementære kropslige lyst- og ulysttilstande gennem besætning af erindringsbilleder betyder, at fantasiernes genealogi følger de almene udviklingsmønstre og specielt den psykoseksuelle udvikling. Med udgangspunkt i Erik H. Eriksons beskrivelse af den følge af kropszoner og organmønstre, der karakteriserer barnets udvikling vil en sådan fantasiernes protogrammatik blive 
søgt fremstillet.

Udgangspunktet for Eriksons udviklingsskema er Freuds skelnen mellem det orale, det anale og det falliske stade. Erikson udbygger Freuds beskrivelse først og fremmest gennem tilføjelsen af de såkaldte organmønstre, kropslige adfærdsmønstre, til de erogene zoner. Han opregner følgende fem fundamentale organmønstre: 1) det inkorporerende, 2) det fastholdende (bidende), 3) det tilbageholdende, 4) det eliminerende og 5) det indtrængende. Grafisk fremstiller Erikson dem således:

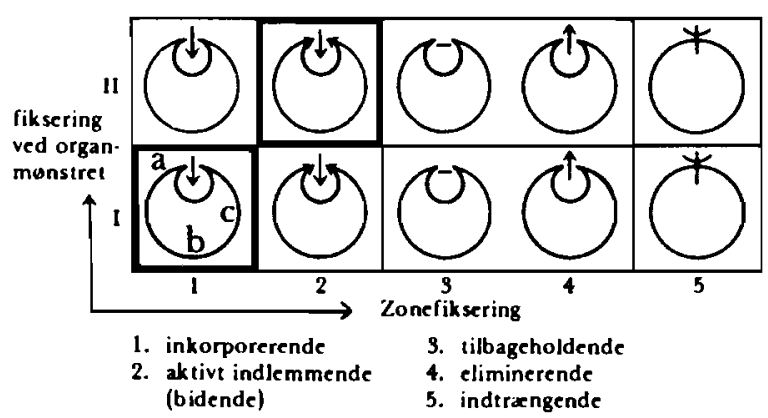

(Den store cirkel betegner hele organismen, den lille den relevante kropszone. a, b, og $\mathrm{c}$ angiver henholdsvis den orale, den anale, og den genitale zone)

Eriksons pointe er, at alle fem organmønstre eksisterer fra først af, men at ét, det oralt-inkorporerende er dominerende ca. det første halve år af barnets liv, da barnet er hjælpeløst og afhængig af inkorporeringen af den tilbudte føde, mælken. Erikson ser stade og mønster koncentreret om mund, svælg og moderens bryst, men han kalder alligevel stadiet det oralt-respiratorisk-sensoriske, fordi hele kroppen, og specielt huden, inddrages i den symbiotiske interaktion mellem barn og plejende person (moder). De fire andre, ikke-dominante, organmønstre fungerer som hjælpemønstre, men de kan aktualiseres som dominerende mønstre, såfremt omstændigheder vedrørende plejen fremmer dem på bekostning af det inkorporerede mønster.

I det sene orale stadium, ved og efter tændernes fremkomst, sker en overgang til organmønster 2 (det fastholdende, bidende). Barnet kan ikke undgå den smerte tandfrembruddet fremkalder i dets mundhule, hvad der fører til raserianfald, og biden optræder altid i et fors $\emptyset \mathrm{g}$ på at mindske smerten og som en reaktion på den. Barnets biden bringer det også i konflikt med moderen, specielt hvis hun ammer. Barnets fors $\emptyset \mathrm{g}$ på at fastholde, bide sig fast og bide i stykker mødes uvægerligt med en tilbagetrækning af brystet.

Det unge barns fantasiaktivitet, der af psykoanalytikerne, specielt kleinia- 
nerne, beskrives som særdeles voldsom, kan ikke fremstilles som et indre teater, hvor spædbarnet overværer sit eget stykke. Snarere må man forestille sig den som en kropslig og psykisk aktivitet, som barnet er $i$ uden noget skel mellem betragter og betragtet. Endvidere er synet næppe fantasiens, og heller ikke perceptionens, primære medium på dette tidlige tidspunkt. I stedet spiller taktile impulser en afg ørende rolle: læbernes runding om fødekilden (e.g. brystvorten), væskens strømmen i mundhulen, fornemmelsen af at blive båret óg vugget, af varme og kulde, irritationen af huden eller lysten ved kærtegn, etc. Spædbarnets afhængighed og passivitet gør det også til offer for indre impulser, mangeloplevelser og smerte og ude af stand til at flygte fra udefra påført smerte og ubehag. Og spædbarnets reaktion på lyst og ulyst er umiddelbar og voldsom.

Fantasier, der antages at optræde i det tidlige og sene orale stade anses for at have brystet (eller fødekilden) som partialobjekt, idet moderen som totalobjekt først langsomt gennem denne periode dannes for spædbarnet. Men heller ikke brystet antages at foreligge som en énhed for barnet. I stedet er det spaltet $\mathrm{i}$ forhold til lyst-ulyst dikotomien i det såkaldte gode og onde (d.v.s. frustrerende) bryst. Det primære organmønster er i det tidlige orale stade det inkorporerende, og en typisk fantasi er således inkorporationen af det gode bryst, at have det inden i sig selv. Den modsatte fantasi om det onde bryst knytter sig til det eliminerende organmønster, at spytte det ud. I relation til det fastholdende, bidende organmønster fantaseres om at bide brystet itu, splitte det ad og opæde det; medens fantasien om at beholde brystet inden i sig er knyttet til det retenderende mønster, og fantasien om at trænge ind $i$ brystet er knyttet til det indtrængende. Spædbarnet erfarer imidlertid også sit kropsindre som et rum for ukontrollable og ofte uvelkomne impulser. Med disse kropslige fornemmelser korreleres fantasier, der er knyttet til de samme organmønstre, men som tager egenkroppen som fantasiobjekt, altså at blive inkorporeret, sønderbidt, spyttet ud, fanget indeni og læderet af et indtrængende objekt (for dette se Isaacs 1948).

I tilgift til fantasier knyttet til den orale zone findes også nogle knyttet til den kropslige og psykiske almentilstand. Freud forklarer f.eks. den såkaldte oceaniske følelse, subjektets forbundethed med altet, på følgende måde:

»Oprindelig indeholder Jeg'et det hele, senere skiller det en omverden ud af sig. Vor nuværende Jeg-følelse er således kun den indskrumpede rest af en mere omfattende - ja, af en altomfattende - følelse, hvortil der svarede en mere inderlig forbindelse mellem Jeg og omverden. Hvis vi kan tillade os at gå ud fra, at denne primære Jeg-følelse i større eller mindre udstrækning er blevet opretholdt i mange menneskers sjæleliv, 
hvor den altså optræder som en slags modstykke til den modne alders snævrere og mere skarpt afgrænsede Jeg-følelse og side om side med denne, vil det forestillingsindhold, der skulle svare til den, netop være den ubegrænsethed og den forbundethed med Altet, som min ven beskrev som en »oceanisk« følelse.« (Freud 1966 (1930a):13)

Den lystfyldte symbiose som spædbarnet oplever i de tilfredsstillende samspil med den plejende, som ikke klart er skilt fra det selv, tryghedens og lystens grænseløse tilstedeværelse, er måske prototypen på begæret efter og fantasien om en forskelsudviskende, ordløs opgang i en universel harmoni, en slags unio mystica. Omvendt bevirker oplevelsen af og erindringen om mangel, smerte og forladthed følelsen af og fantasien om et globalt sammenbrud. ${ }^{2}$

De tidlige fantasier synes således knyttet til organmønstre, der kan beskrives ved hjælp af en række basale modsætninger: at indeholde vs at vare indeholdt, at bide/sønderbide vs at blive bidt/sønderbidt, at tilbageholde vs at blive tilbageholdt, at udstøde vs at blive udstødt, at trange ind $i$ vs at blive trangt ind $i$. Alle modsætningerne betegner forskellige former for legemers, legemsstoffers og legemåbningers forhold til hinanden, og naturligvis har fantasierne herom et afgørende fundamentum in re. Det er imidlertid værd at bemærke, at disse kontakter, bevægelser, overførsler og destruktive handlinger alle forudsætter grænser mellem to legemer. Disse grænser eksisterer naturligvis i fysisk forstand, nemlig som grænsen mellem egenkrop og fremmedkrop. I spædbarnets psykiske realitet antager psykoanalysen imidlertid hverken at disse grænser er faste eller erkendte. Tværtimod etableres skellet mellem ydre og indre hos spædbarnet ifølge Freud efter et helt andet princip:

»En yderligere anledning til løsrivelse af Jeg'et fra den samlede fornemmelsesmasse, altså til anerkendelse af et »udenfor«, af en omverden, giver de hyppige, mangeartede og uundgåelige smerte- og ulystfornemmelser, der opfordrer til at ophæve og undgå det ubegrænset herskende lyst-princip. Der opstår en tendens til at skille alt, hvad der kan blive kilde til ulyst af denne art, ud fra Jeg'et og skyde det udefter, og dermed en tendens til at danne et rent Lyst-Jeg, der er stillet over for et fremmed, truende »udenfor «. Grænserne for dette primitive Lyst-Jeg kan ikke unddrage sig korrektion gennem erfaringen. Meget af det, man ikke gerne vil opgive som lyst-givende, hører til syvende og sidst ikke til Jeget, men er objekt, og mange lidelser, som man gerne vil skyde fra sig, viser sig alligevel at være uadskillelige fra Jeg'et, idet de stammer indefra. Man lærer en fremgangsmåde at kende, hvorved man gennem vilkårlig styring af sansevirksomheden og hensigtsmæssig muskelaktion 
kan sondre mellem det indre - det Jeg'et tilhørende - og det ydre - det fra omverdenen stammende, og man gør derved det første skridt til at knæsætte realitetsprincippet, der skal komme til at beherske den videre udvikling. « (Freud 1966 (1930a):12)

Det er væsentligt at fastholde kompleksiteten i Freuds tankegang, hvor to samtidigt foregående og hinanden modsigende processer er på spil. På den ene side de to ældste psykiske forsvarsmekanismer, introjektionen og projektionen (dannet i relation til organmønstrene inkorporation og elimination), hvorigennem grænsens ydre/ indre søges lagt ved grænsen mellem lyst og ulyst. På den anden side den langsomme opbygning af en grænse mellem egenkrop og objekt, og af et kropsbillede og en omverdensperception, der, mere eller mindre, er i overensstemmelse med den ydre realitet. Uden at være opmærksom på, at spædbarnets fantasiliv foregår både $\mathrm{i}$ konflikten mellem og som en mediering af disse processer, bliver psykoanalysens fremstilling af det uforståelig. Man må forestille sig, at fantasierne nedbryder grænser, som kun er rudimentære og labile, således at der sker tilbagegribende reartikuleringer af labile forestillingsindhold og relationer. If $\varnothing$ lge den kleinianske tradition skulle f.eks. en vigtig psykisk mekanisme som reparationen (som siges at optræde fra ca. fjerde levemåned) d.v.s. forsøget på at retablere et indre, psykisk objekt, som barnet selv har destrueret i fantasien, både forudsætte, at totalobjektet (e.g. moderen) kendes og introjiceres; men samtidig er mekanismen selv med til at stabilisere det totale objekt som en psykisk realitet. Med denne mekanisme suppleres modsætningsparrene smerte vs tilfredsstillelse og lyst vs ulyst med den processuelle modsætning mellem at destruere og at reparere/at hele.

Det sene orale stade falder nogenlunde sammen med det narcissistiske trin i jeg-udviklingen, som er karakteriseret ved magisk tænkning, d.v.s en tro på tankens og ønskets magt over objektet. For fantasilivet bliver der således tale om almagtfantasier, hvor barnet synes at beherske omverdenen, specielt moderen. Disse fantasier balanceres imidlertid af afmagtsfølelsen i forhold til den aktive og (nødvendigvis) dominerende, ja, almægtige moderskikkelse, som barnet både identificerer sig med og reagerer aggressivt imod. Det såkaldte moderimago er, som andre imagoer, en fantasmatisk strukturering af interaktionen med moderen, et affektivt ladet betydningsmønster, hvis elementer hentes fra barnets egen psykiske realitet.

Det anale stade kaldes af Erikson det anal-uretral-muskulare stadium. Herigennem understreges det almene psykoanalytiske synspunkt, at de anale og uretrale funktioner, hvis regulering (i vor kultur) kan medf $\varnothing r e$ veritable kampe mellem barnet og moderen, indgår i et langt større konfliktfelt. Hovedmodsætningen i denne fase er mellem at vare passiv og at vore aktiv. Barnets 
større beherskelse af muskulaturen forøger naturligvis antallet af konflikter med omverdenen, hvor svaret på barnets aktive adfærd netop vil bestå i forskellige former for passivisering. At det anale og uretrale område bliver brændpunkt for konflikter, og i fantasierne, er der to vigtige grunde til. For det første den almene grund, at legemets åbninger og legemets udsondringer altid er prekære, fordi de relativerer grænsen mellem ydre og indre, synes sårbare og danner passager for udveksling mellem subjekt og omverden. For det andet er udskillelsen af affaldsstoffer, mere eller mindre, kulturelt reguleret og tabueret. De dominante organmønstre for dette stadium er, ifølge Erikson retention og eliminering:

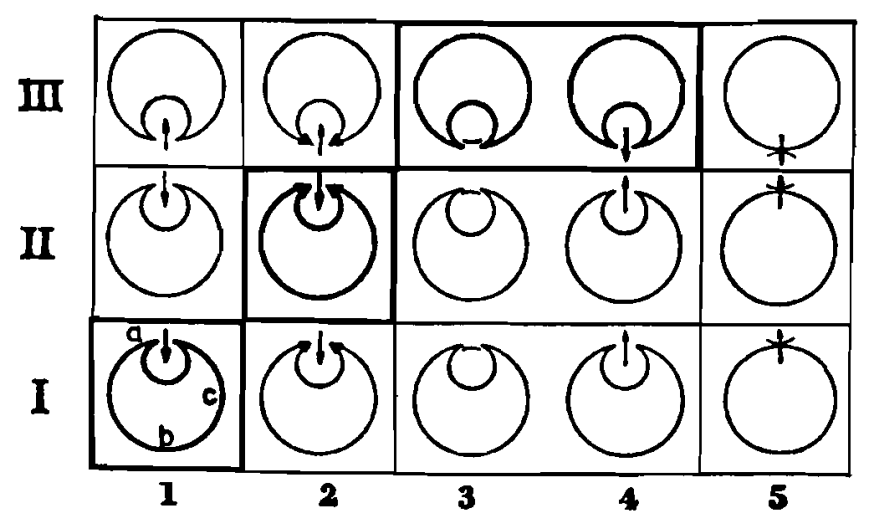

(Erikson 1971: 72)

Urin og fæces kan med en øget beherskelse af muskulaturen (i et vist omfang) beholdes indeni eller tømmes ud i omverdenen. Derfor kan funktionerne blive udtryk for kærlige og aggressive handlinger, for hævdelse af selvstændighed eller føjelighed og for beherskelse eller afmægtighed. Endvidere rummer produkterne og akterne modsætninger, ja, ofte regelrette modsigelser: lyst og ulyst både ved tilbageholdelse og udskillelse, følelse af at afgive en del af sit indre vs stoltheden ved at producere, andres henholdsvise ros og udskamning, deres bifald ved processen, men ækelhed ved produkterne, og forbundet hermed, oplevelsen af at give en gave, som både er ønsket og uønsket. Og dermed også inderliggørelsen af denne ambivalens i forhold til kropsdele, legemsfunktioner og produkter. Intet under at floraen af fantasier, ubevidste såvel som bevidste, vedrørende det uretrale og anale er mangfoldig. Ved siden af fantasier om at udstøde og destruere objektet findes fantasier om at beher- 
ske det ved at beholde det $\mathrm{i}$ sit indre. Fantasier om at bombardere eller drukne, og trænge ind $i$ det ved hjælp af fæces og urin, at inkorporere gennem anus. Korresponderende, men modsatte fantasier om at blive jaget, druknet, bombarderet, om at indeholde eksplosiver eller gift, om at blive trængt ind i, etc. Karakteristisk for disse fantasier er deres aggressive og destruktive karakter. Derfor er analerotikken og den sadomasochistiske perversion, ifølge psykoanalysen, tæt forbundne, bl.a. fordi trods og ydmyghed, beherskelse og underkastelse og tilføjelse af smerte over for modtagelse af smerte er artikulationer af modsætningen mellem aktiv og passiv. Også de modsætningspar Erikson anvender til at karakterisere stadiet, selvstandighed over for skamfølelse, forekommer at være en særlig artikulation af aktiv-passiv modsætningen. Udover focuseringen på det anale og uretrale er stadiet mere alment karakteriseret ved en mærkbar vekslen mellem løsrivelse fra og gentilnærmelse til moderen; men denne proces er allerede begyndt i det orale stade.

I Eriksons formulering af stadie-teorien for den psykoseksuelle udvikling bliver, hvad der traditionelt betegnes det falliske stadium, omtalt som gangens og den infantile seksualitets stadium. Pointen er, at to ting falder sammen for barnet ved slutningen af det tredie leveår: Evnen til at gå og løbe ubesværet (selv om det har kunnet gå før dette tidspunkt), og zoneskiftet til det genitale område, hvor Erikson, i overensstemmelse med den klassiske psykoanalyse, ser hovedmodsætningen som fallisk vs kastreret. Overgangen til dette fjerde stadium (Erikson skelner jo to orale stadier) og hele udviklingsmatrixen fremstiller han grafisk som følger:

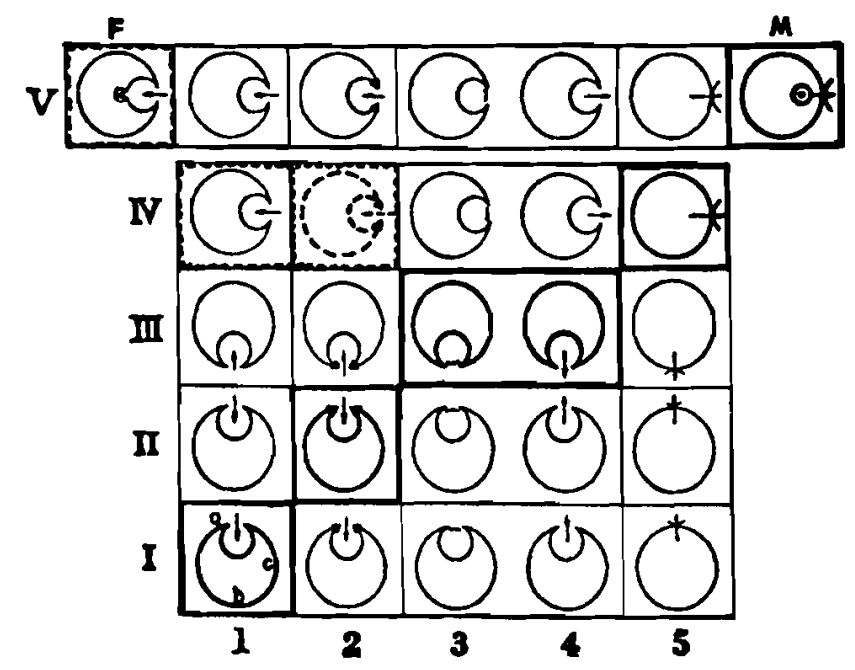

(Erikson 1971: 78) 
For begge køn ser Erikson det indtrangende organmønster som dominerende. Indtrangende skal både forstås snævert forbundet med det falliske og bredt som aggressiv trængen sig ind på/i andre fysisk og verbalt, trænge ind $i$ fremmed rum og trænge ind $i$ det uforståelige for at erhverve viden og mætte sin nysgerrighed, at se hvad der ikke bør ses, og vise hvad der ikke bør vises. Centralt står kønsforskellens mysterium og de "forklaringer," den fremkalder: spørgsmålet om børns oprindelse (de infantile seksualteorier om etkønnethed, den kloakale fødsel og samlejet som aggression), og det incestuøse begær rettet mod forældre og søskende. Freud udskiller en lille eksklusiv gruppe af fantasier, der også er knyttet til den infantile seksualforskning, de såkaldte urfantasier. I Forelasninger til indføring i psykoanalysen (1916-17) nævner Freud tre sådanne som eksempler på denne eksklusive gruppe, nemlig: fantasien om at blive truet med kastration eller blive kastreret, fantasien om at overvære forældrenes samleje (urscenen) og fantasien om at være blevet forført af et familiemedlem, e.g. en af forældrene. Til disse føjer Freud i en note til Tre afhandlinger... yderligere to: fantasien om ophold i moderens liv og den såkaldte familieroman, d.v.s. fantasier om at være hittebarn, bastard eller den agtefødte blandt en søskendeflok af bastarder (cf. Freud (1905 d) 1985:121n.). Til disse fem kunne man nok tilføje fantasien om faderdrabet, der spiller så stor en rolle i Totem og tabu (1912-13), den aktive fantasi om at besidde moderen seksuelt eller at få et barn med faderen og afstraffelses- eller pryglefantasierne, som Freud selv indgående har beskrevet (Freud 1919e).

I hvert fald hvad de tre første angår, fremsætter Freud en ganske uacceptabel hypotese, nemlig, at disse fantasier rummer fylogenetiske træk. Han siger, at "individet søger i disse fantasier tilbage hinsides sin egen oplevelse, til fortidens oplevelse, når dets egen er blevet alt for rudimentær «, og videre, »at det fantaserende barn ganske simpelt har udfyldt den individuelle sandheds lakuner med præhistorisk sandhed « (Freud (1916-17) 1965:294). Tesen er ganske uunderbygget, og den er unødvendig. For selv om Freud nok har ret i, at disse fantasier optræder med en forbavsende hyppighed, der er større end en fundering i konkrete, tilsvarende barndomsoplevelser retfærdiggør, så kan deres hyppighed gives en anden forklaring, nemlig: at der er tale om tilbagefantaseringer og den såkaldte efterlods virkning (Nachträglichkeit), der spiller en stor rolle i Freuds forklaring af symptomdannelsen. ${ }^{3}$

Ifølge klassisk psykoanalytisk tankegang er penis, eller snarere dens psykiske repræsentation som fallos, det privilegerede partialobjekt på dette stadium. Den er både et forskelssattende element i relationen mellem kønnene og generationerne og et objekt ladet med begær og angst, der er selvstændiggjort, så den cirkulerer mellem (hoved)personerne på fantasiens scene (cf. fantasier om den såkaldte falliske moder og den kombinerede foraldrefigur). 
De ovenfor nævnte urfantasier er primært ødipale; og til Ødipus-komplekset er knyttet teorierne om drengens og pigens forskellige skæbner på dette tidspunkt. Den diskussion, disse teorier har vakt, skal ikke berøres her (for en glimrende og omfangsrig fremstilling se Andkjær Olsen 1988). Imidlertid skal Eriksons afrunding af det epigenetiske diagram for barnets udvikling frem til den såkaldte latensperiode nævnes (Eriksons fulde epigenetiske model rækker helt frem til den modne alder). Han bygger sin beskrivelse på den klassiske opfattelse af drengens og pigens forskellige skæbne under $\varnothing$ dipus-komplekset. Det dominerende organmønster for begge køn er ved stadiets begyndelse det indtrængende; men netop pigens oplevelse af den ødipale konflikt og af sig selv som "kastreret « (cf. det hidsigt debatterede begreb om penismisundelse) fører, ifølge Erikson, til at hun skifter mønster og delvis griber tilbage til det inkorporerende, det mønster der var dominerende i den orale fase. Erikson tilføjer et femte stadium, hvor de ekstra cirkler betegner et henholdsvist kvindeligt (VF) og mandligt generativt (VM) mønster, altså et rudimentært seksualt-produktivt organmønster, der foreligger som en uklar anticipering af forplantningen.

I skitsen af de psykoanalytiske teorier om den psykoseksuelle udvikling og fantasilivet til og med den falliske fase og Ødipus-kompleksets optræden har nogle typiske fantasier været nævnt: Inkorporationsfantasier knyttet til fødeindtagelsen og fantasien om samhørigheden med altet. Udstødnings- og tilbageholdelsesfantasier i forbindelse med det anale og uretrale, de tre typiske fantasier knyttet til barnets seksualforskning, tilskrivning af en penis til alle (etkønsteorien), fantasien om den kloakale fødsel og fantasien om samlejet som en sadistisk handling. Urfantasierne: beluringen af forældrenes samleje (urscenen), truslen om kastration, forførelsesfantasien, fantasien om opholdet i moderens liv, familieromanen. Jeg selv tilføjede faderdrabet, fantasien om at besidde moderen seksuelt, fantasien om at få et barn med faderen og pryglefantasien til listen over vigtige ødipale fantasier.

Disse typiske fantasier kan anskues som ofte forekommende syntagmer $i$ psykoanalysens fremstilling af det infantile fantasilivs leksikon, syntaks og funktion (pragmatik om man vil). Eriksons fremstilling af den psykoseksuelle udvikling er en art matrix, der viser sammenhængen mellem, men også den relative selvstændighed af de kropszoner og -åbninger og adfærdsmønstre, der er funderet i nødvendige og mere eller mindre reflektoriske kropsfunktioner. Ud fra dette synspunkt er fantasilivet således modelleret over den kropslige adfærd og interaktion; men det selvstændiggøres efterhånden og de basale organmønstre bliver til metaforer, selv om de i arkaiske, ubevidste fantasier stadig er næret af deres kropslige substrat.

De tidlige fantasiers protoleksikon er partialobjekterne: e.g. brystet, fæces 
og penis. Partialobjekterne har fem mærkværdige egenskaber: 1) Deres lokalisering er foranderlig, for de kan både opfattes som en del af egenkroppen og som fremmedlegemer. 2) De spaltes ofte i to, et godt og et ondt, et ønsket og et frygtet. 3) De kan i et vist omfang substitueres for hinanden, låne egenskaber fra hinanden eller symbolisere hinanden. 4) Totalobjektet kan identificeres med eller i det væsentligste være karakteriseret som et partialobjekt. Og 5) partialobjekterne kan danne udgangspunkt for såkaldte ækvivalensrækker, hvor de akvivaleres med hinanden (cf. 3) og med andre objekter, således at de sidste investeres med en del af de førstes driftsenergi (det klassiske eksempel er Freuds ækvivalensrække: fæces - penis - gave - barn - penge, (cf. Freud 1917c). Idet de optager skiftende positioner inden for organmønstrene bliver partialobjekterne privilegerede elementer i primærprocessens spil af forskydninger og fortætninger.

I partialobjekternes spaltning (cf. punkt 2) ligger allerede fantasiaktivitetens artikulation i forhold til modsætningen mellem lyst og ulyst, og hertil kommer de to øvrige kanoniske modsætninger, aktiv vs passiv (der egentlig også rummer en tredie artikulation, nemlig refleksiv, d.v.s. subjekt og objekt er knyttet til samme person) og fallisk vs kastreret. De tre artikulationsmåder bygger oven på hinanden, kombineres indbyrdes og forbindes på forskellig vis med organmønstrene. Disse kombinationer er ikke tilfældige, men en effekt både af den psykiske udvikling og af kulturelle mønstre; men de er langt mangfoldigere, end man er tilbøjelig til at tro, noget bl.a. psykopatalogien kan bekræfte.

Punkt fire (ovenfor) nævner modsætningen mellem partial -og totalobjekterne. Disse kan i fantasilivet meget vel eksistere side om side; og i den psykiske repræsentation af interindividuelle konflikter kan kampen netop stå om partialobjektet (e.g. fallos' cirkulering i ødipale fantasier). At partialobjekterne afløses af totalobjekterne fremstilles som et moment i den psykiske udvikling; men i det ubevidstes holografiske univers, betyder det kun at nyt føjes til uden at gammelt nødvendigvis forsvinder. Freud har fors $\varnothing \mathrm{gt}$ at billedligg $\varnothing \mathrm{re}$ denne samtidighed således:

»Lad os nu gøre den fantastiske antagelse, at Rom ikke er et menneskeligt beboelsesområde, men et sjæleligt væsen med en tilsvarende lang og omskiftelig fortid, hvor altså intet af det, der én gang var kommet i stand, er gået til grunde, men hvor alle tidligere udviklingsfaser stadig består ved siden af den sidste fase. Dette ville da for Roms vedkommende betyde, at kejserpaladserne og Septimus Severus' septizontium stadig ville rejse sig i deres gamle højde på Palatinerhøjden....

Hvor Coliseo nu står, ville vi også kunne beundre Neros forsvundne Domus aurea; på Pantheon-pladsen ville vi ikke alene finde det nuvæ- 
rende Pantheon, således som Hadrian har efterladt os det, men vi ville på den samme grund også finde Marius Agrippas oprindelige bygning; ja, den samme grund ville bære kirken Maria sopra Minerva og det gamle tempel, over hvilket den er bygget. Og det eneste, der ville være nødvendigt for at fremkalde det ene eller det andet syn, var måske en ændring af synsretningen eller af iagttagerens ståsted.«(Freud 1965 (1930a):15-16)

I forlængelse af Freuds billede må en mærkværdighed imidlertid understreges, for at det skal kunne fungere som metafor for psyken; nemlig, at de sten, der er brudt fra en ældre bygning for at opføre en ny samme sted, i psyken samtidig befinder sig i begge bygninger. I de ubevidste fantasier, og også i et vist omfang i dagdrømmen, betyder dette, at de enkelte elementer mister deres identitet $o g$ forlenes med betydning i samspil med deres i sig selv labile kontekster. ${ }^{4}$

Labiliteten har imidlertid sine grænser. Hvis forskydningerne og fortætningerne ikke også i det ubevidste formede et mønster, ville enhver karakterdannelse umuliggøres, og centrale psykoanalytiske begreber som fiksering, regression og fortrangning ville blive meningsløse. Ja, selv ideen om den hallucinatoriske фnskeopfyldelse, der if $ø$ lge Freud anses for at være en primær psykisk aktivitet, forudsætter en genbesætning af hukommelsesspor, altså en minimal forestillingsmæssig stabilitet. Dobbeltheden af labilitet og stabilitet $i$ det ubevidste fantasiliv er bl.a. en effekt af, at en stadig strom af forskellige objekter (objektsrepræsentanter) skiftes til at indtage samme pladser i en forholdsvis stabil struktur, en art narrativt fragment, der som sin kerne indeholder den imaginære tilfredsstillelse af specifikke driftsmål, eller - mere i overensstemmelse med den psykiske realitet - indeholder konflikter mellem forskellige driftsmål.

En anden dobbelthed i psykoanalysens opfattelse af fantasierne er deres relation til det fantaserende subjekt. I løbet af den psykiske udvikling selvstændiggøres subjektet i forhold til sit eget fantasiliv ved hjælp af realitetsprøven, styrkelsen af jeg'et og erhvervelsen af sproget (faktisk tre sider af samme sag). Fra at vare i fantasierne, som ikke skelnes fra den ydre realitet, udvikler subjektet sig til at have fantasier, til tilsyneladende vilkårligt at kunne producere dem. Imidlertid er dette kun den halve sandhed, for fantasierne vedbliver at være en del af subjektets psykiske realitet. De bevidste fantasier tilkendes ganske vist ingen realitet og synes kontroller- og manipulerbare; men subjektets suverænitet i forhold til dem er kun tilsyneladende. Styrkelsen af jegfunktionerne, sekundærprocessernes overlejring af primærprocesserne etc. finder sted samtidig med og forudsætter subjektets spaltning $i$ bevidst og ubevidst. Derfor er dets magt over fantasierne meget begrænset, ja, mestendels 
illusorisk. Ikke blot magten over de fortrængte og ubevidste fantasier, som det er uvidende om, men også over de bevidste, fordi de sidste og de første er forbundne. Den tvangsmassige dagdrømmer kan nok »spole tilbage « og »redigere«, ja, udbygge sin forestillingsaktivitet gennem »research «, altså samle på situationer, billeder, lekture, der nærer hans fantasi; men det hele foregår efter et ubevidst manuskript, som han hverken kender eller behersker.

\section{Theatrum mundi}

Privatteatret med dets to forbundne scener, hvor vi kun ser spillet på den ene, men opfanger den andens spil som en uforklarlig fryd eller angst, er vi ene om. Oftest værner vi om dets eksklusivitet. Og i øvrigt kan vi strengt taget ikke invitere nogen indenfor, for vore fantasier ser eller sanser vi, og det er et syn, vi ikke kan dele med andre.

Dog, hvad der foregår på disse scener, det »fredede område i sjælen « eller "mellemriget " som Freud kalder det, er eksistentielt betydningsfuldt. Fantasilivet rummer nemlig endnu en dobbelthed: På den ene side er det netop et "naturreservat « unddraget de forpligtelser og konsekvenser, der behersker vor sociale interaktion. På den anden side er fantasiaktiviteten bundet til begærets og angstens fortrængte historie, bundet til i forskellige kostumer at gentage ubevidste scenarier. Disse scenariers detaljer er ganske vist individuelle; men de er blevet til inden for en bestemt kultur til en bestemt tid. Det fortrængtes historie må nødvendigvis være forbundet med det fortrængendes, og derfor er det ubevidste også et socialt fænomen. Hertil kommer, at hvis psykoanalysen har ret $i$, at fantasierne i deres tidlige historie er knyttet til oplevelser af kropslig lyst og ulyst i samspillet og udvekslingen med den anden, så er alle fælles om elementære, men fundamentale fantasimønstre.

I fantasien irrealiseres således, hvad der er en erkendt fælles realitet, den sociale livsverden og den fysiske omverden. Samtidig iscenesættes fantasiens imaginære rum bl.a. af en ubevidst psykisk realitet, hvis strukturer i større eller mindre grad er fælles for medlemmerne af en given kultur. Til at dele disse erkendte, anede og uerkendte forestillinger skaber alle samfund forskellige institutioner og diskurser. En af disse er litteraturen, der i vor kultur har selvstændiggiort sig fra sit sakrale udspring og er blevet profan.

Spørgsmålet bliver så, hvad overgangen fra den individuelle forestilling på privatteatret til fremstillingen $p a ̊ a$ den fælles scene, og til fremstillingen af den fælles scene, theatrum mundi, betyder? En vigtig ting er i hvert fald litteraturens eksplicitte eller i det mindste altid implicitte krav på repræsentativitet. Metaforen om verdensteatret (for dens ældre historie se Curtius 1948:148-154) 
prætenderer i sig selv, at litteraturen fremstiller det, som alment karakteriserer den menneskelige eksistens. Aristoteles har frydet alle elskere af litteraturen (og måske irriteret historikerne) lige siden han formulerede digtningens opgave på følgende vis:

»Men det fremgaar også af det sagte, at det ikke er Digternes Opgave at foredrage hvad der virkelig er sket, men hvad der er saadan, at det kan ske og er muligt med Hensyn til Rimelighed eller Nødvendighed. For Historikeren og Digteren er forskellige ikke ved at den ene taler paa Vers, den anden i Prosa, for man kunde meget godt tænke sig Herodots værk sat paa Vers, og det vilde ikke mindre være Historie paa Vers end uden Versemaal, men Forskellen er, at den ene fortæller hvad der er sket, den anden hvordan det skete maatte være for at ske. Derfor er Digtningen baade mere filosofisk og mere etisk end Historien, for Digtningen fremstiller mere det almene, Historien derimod de enkelte Begivenheder.« (Aristoteles 1958:15)

Men hvordan sikrer digterne sig, at de kan løse denne opgave? En måde at gøre det på, og en måde der i hvert fald frem til det 19. århundrede var den mest benyttede, er at genfortalle: »Atter og atter hun bad ham om Trojas Skæbne berette,/ og på forskelligste Vis tit blev det samme fortalt « (Ovid 1943:II, 127-8). At genfortælle myter og sagn eller at forme sin fortælling i relation til dem er en oplagt måde at forsøge at sikre, at det individuelle værk alene i kraft af motiv og stof besidder en vis almenhed. I disse tilfælde, der jo er langt de almindeligste, hentes bærende dele af teksten således ikke fra digterens personlige erindring og ubevidste fantasi, men fra hans læsning. Selv om det foregår i enerum, er at digte i eminent grad en dialogisk aktivitet. Digteren har hele tiden mindst to dialoger gående - hvad enten han ved det eller ej - en med traditionen og en med sit publikum. Og både tilegnelsen af traditionen og dialogen med den er primært en bevidst aktivitet. Store dele af dagdrømmens inventar er selvfølgelig også hentet om ikke fra litteraturen så fra arsenalerne af kulturelle stereotyper. Imidlertid forbliver den afgørende forskel, at digteren ikke blot kan forholde sig receptivt, for traditionen er for ham både stof, teknik og norm. Af denne grund er han nødvendigvis engageret $\mathrm{i}$ litteraturen som artefakt, som kunstværk.

Medens dagdrømmen primært er en ikonisk repræsentation af handlingssekvenser og tableauer, er litteraturen sproglig (symbolsk), og digterens opmærksomhed er ikke blot vendt mod sprogets fremstilling af et imaginært univers, men også mod sprogets materielle og strukturelle egenskaber. Ja, den sproglige artikulation, den rette rytme, det klangfulde ord, de lydlige, syntak- 
tiske og betydningsmæssige forbindelser mellem sætninger og vers eller deres dele er for ham en udfordring og opgave. Og vel at mærke ikke en selvopfunden opgave; for også den poetiske sprogbrug har en historie.

Som offentlig diskurs er litteraturen endvidere forbundet med, og influeret og begrænset af, det sociale liv på utallige måder: Den reguleres af de til enhver tid rådende betingelser for dens produktion, publikum, kommunikationsformer, produktionsteknologi, kredsløb, censur og begunstigelser. Den er endvidere ét medium blandt andre for formidlingen af et givent samfunds eller en given klasses selvbevidsthed. Den litterære diskurs er derfor $i$ en vis forstand altid uren. Når man taler om litteraturen som efterligning eller fremstilling af virkeligheden, må man være opmærksom på, at den snarere efterligner vore forskellige måder at tale om virkeligheden på. Derfor taler andre diskurser i litteraturen: den religiøse, filosofiske, historiske, moralske, politiske, didaktiske, etc. Og de kan vel at mærke ikke trækkes fra, sådan at den rene litterære tekst står tilbage. Litteratur er, ligesom konversation eller brevskrivning, en bestemt måde at tale eller skrive om de forskelligste emner på, blot med flere strukturelle sartræk, kunstgreb og udtryksmuligheder.

Af det forudgående følger også, at det dialogiske forhold til publikum ikke blot er noget litteraturen ydre. Tværtimod er den kommunikative intention nærværende selv i den mest aristokratiske trobar clus eller i det mest intellektualistiske modernistiske digt. Eliot udtrykker det således: »Min opfattelse er, at et godt kærlighedsdigt, skønt det måske er addresseret til én person, altid er bestemt til at blive lyttet til af andre. Sikkert og vist, kærlighedens sande sprog - at sige det, som kun meddeler sig til den elskede og til ingen anden - er prosa«. (Eliot 1957 (1953):90)

Fra privatteater til verdensteater er der altså nok så stort et spring. Sat på spidsen kunne man sige, at digteren drømmer andres drømme, at han er et led $i$ og engageret $i$ en tradition, som former ham, at digtning for ham er et håndværk, hvis værktøjs muligheder optager ham meget, at han som professionel er integreret $i$ et litterært system, der opfylder en række forskellige funktioner og imiterer alle slags tale, og at han aldrig taler intimt eller fortroligt, hans hvisken er altid teaterhvisken.

I forhold hertil synes udsigterne for psykoanalysens tolkning af litterære tekster dystre. Og de er, eller rettere ville være, dystre, såfremt den var den eneste tilgang; og såfremt den gjorde krav på at være udtømmende. Men psykoanalysen gør kun krav på at udtale sig om en dimension i den litterære tekst, omend en vigtig. Og desuden har litteraturen også som offentlig diskurs en anden side end den netop nævnte.

Totus mundus agit histronem stod der på vimplen over Globe Theatre; altså en påstand om overensstemmelse mellem to spil, det der spilles for os, og 
det vi spiller med i. Metaforen om verdensteatret bygger således på den antagelse, at vi bevæges og bliver klogere, fordi vi er tilskuere til os selv. Til den individuelle fantasis dobbelte scene svarer således dubleringen af livets spil med kunstens. Metaforen rummer dog mere: Et skuespil er ikke en imitation af konkrete personers handlinger, det er skabelsen af et selvstændigt univers, adskilt fra vores af rampen, hvor noget, der aldrig har fundet sted, finder sted for vore øjne. Og det finder kun sted i kraft af, at nogen har skrevet det. Selv om vi ser bort fra metaforens religiøse implikationer, ligger der stadig i den, at der er tale om en skabt orden, et fremstillet kosmos. Litteraturen fremstiller således en forestillet orden, som var den virkelig. Og hermed overlever den magiske overensstemmelse mellem tanke og virkelighed, der har rødder $\mathrm{i}$ narcissismen, i litteraturen - men i ændret skikkelse. I stedet for kun at være bundet til den individuelle erindring eller fantasi om en specifik lystopfyldelse eller et specifikt mareridt bliver den til et ønske om at skabe en eksistentielt relevant orden. Genfortællingen af de samme historier betyder derfor ikke, at de mister deres forbindelse til lysten, angsten og fantasierne. Det betyder snarere at de bliver paradigmer for dem, i kraft af hvilke de kan tænkes og deles.

Den litterære traditions stadige omskrivning og omtolkning, dens støbning af gammelt stof i nye former og nyt i gamle, er en bestræbelse på at gøre historien samtidig, men på nutidens præmisser. Den traditionsbevidsthed, der er en del af litteraturen, forhindrer naturligvis ikke, at temaer og udtryk fornys og andet forkastes eller glemmes. Litteraturens erfaringsgrundlag følger nødvendigvis civilisationens forandring; og som et medium for artikulation og formidling af kulturel identitet forhandles betydninger og værdier til stadighed i den. For den psykoanalytiske tolkning af litteraturen som fantasiaktivitet betyder det, at det historisk specifikke og det intentionelle, det bevidst dialogiske moment, aldrig kan overses som noget udvendigt, fordi denne gestaltning er måden, hvorpå digteren tilegner sig den fantasi, han deler med andre. At gå fra teksten til dens stof er således, i hvert fald i en vis forstand, at gå fra elementer og strukturer, der muligvis skylder ubevidste processer og fantasier deres eksistens, til tekstelementer, hvis nærvær skyldes bevidst traditionsformidling. Alligevel kan man ikke se bort fra den traderede fabel af to grunde. For det første er overleveringen modspillet til tekstens egen artikulation af begæret og konflikten. Fablen bliver altså det, teksten skal forklare eller bortforklare. Her kan det, for det andet, vise sig, at fablen er stærkere end den version, som den giver i teksten, d.v.s., at den står tilbage som en modstand f.eks. mod rationalisering eller sentimentalisering (tragedien i det 18. årh. løber ofte ind i dette problem). Den psykoanalytiske tolkning må derfor være dobbelt: både en eftervisning og tolkning af paradigmet, der må være historisk 
og litteraturhistorisk informeret, og en begribelse af den tekstlige egenart som den tidsmæssigt specifikke og individuelle tilegnelse af mønstret. Et mønster der altså kan artikulere en fantasi, som digteren principielt kan være uvidende om.

I den psykoanalytiske beskrivelse af det infantile fantasiliv betragtes de typiske fantasier som en art krystallisationspunkter, som bevidste og bevidste tableauer, der anskueliggør subjektets lyst- eller ulystfyldte forhold til objekterne. De er kulminationerne på barnets tolkningsarbejde (cf. den infantile seksualforskning). I litteraturen derimod optræder sådanne typiske fantasier $\mathrm{i}$ ændret skikkelse som ready mades, som symboler, motiver, elementære narrative strukturer og aktant- og aktørkonstellationer (cf. eventyrene). Derfor er påvisningen af deres tilstedeværelse i den litterære tekst $i$ lige så høj grad en litteraturvidenskabelig pointe, som en psykoanalytisk. Og derfor går der ingen lige vej fra en sådan påvisning til digterens ubevidste. Men naturligvis er en psykobiografisk tolkning af et forfatterskab mulig. For hvis valget og håndteringen af sådanne ready mades danner et mønster, og hvis de optræder sammen med genkommende fantasimønstre af mere individuel art, så er der ingen grund til ikke at forsøge at knytte en sådan personlig mytologi til forfatterens liv og levned. Spørgsmålet er snarere, hvor interessant denne kobling er for læseren og forskeren?

Psykoanalysens bidrag til forståelsen af fantasilivet kan måske bedre inspirere litteraturforskningen på et mere alment niveau, nemlig ved relateringen af de typiske fantasier til de enkelte stadier i den psykiske udvikling og specielt gennem tolkningen af dem som tegn på kriser i forholdet mellem subjekt og omverden. Disse kriser har ganske vist et fundament i virkeligheden; men de udspiller sig i barnets sind efter egne love. Samtidig med at de artikulerer manglen, lysten og den voldsomt oplevede konflikt eller salighed, er de også intellektuelle præstationer, rudimentære antropogonier. Det er redegørelsen for sammenhængen mellem begær og frygt, billeddannelsen knyttet til kroppen og det magiske fors $\emptyset \mathrm{g}$ på at forstå og bemestre omverdenen, der er af eminent interesse for studiet af litteraturen, fordi parallellen til denne, uden at deres forskellige trinhøjde må negligeres, er så slående.

Hertil kommer, at fantasiens teknikker, som psykoanalysen fremstiller dem, genkendes i digtningens kunstgreb. Blot opererer fantasien primært på tingsforestillingerne, medens den digteriske teknik både omfatter billeddannelsen (e.g. metaforen) og bearbejdelsen af sprogets materielle, dets lydlige (og grafiske) aspekt. I digtningen som håndværk - og der må insisteres på, at det er den - ligger også, at dens materielle aspekt er håndgribeligt, sanseligt nærværende og ofte genstridigt, men at arbejdet med det er begærsmættet og lystfyldt eller pinefuldt. På samme vis forholder det sig med den der lytter. Hele- 
na siger til Faust:

"Ein Ton scheint sich dem andern zu bequemen,

Und hat ein Wort zu Ohre sich gesellt,

Ein andres kommt, dem ersten liebzukosen.«

(Faust II, III, 9369-71)

Den digteriske teksts håndgribelighed er en erotisering af udtrykket ligesåvel som tekstens univers er fremstilling af begæret. ${ }^{5}$

Digtningens mange funktioner, og dens kamæleonagtige tagen farve efter de andre sociale diskurser den tjener, betyder ikke, at den helt mister et vigtigt kendetegn, nemlig at være emotionelt engageret og engagerende udkast til mulige, men alligevel konkrete verdener. Selv når en oplysningsfilosof bruger fiktionen til at propagere mod autoriteter, misbrug og almindelig forstokkethed, så engageres han af sin egen forestillingsevne til at konkretisere, hvad der måske blot var tænkt som et folie for argumenterne (cf. Voltaires eventyr og historier og Diderots glimrende La religieuse). At fiktionaliseringen som oftest fører forfatteren til egne af psyken, som han måske tror er sagen uvedkommende, beror på, at når fantasien hidkaldes, så sættes kræfter i gang og betydninger på spil, som har deres egne love og mål.

Når litteraturen - denne på én gang klæbende og proteusagtige diskurs - i moderne samfund er selvstændiggjort og har sine egne institutioner, skyldes det, at homo sapiens åbenbart behøver omverdens- og selvtolkninger, der involverer hele eksistensen og hele den psykiske realitet. Dens strenge onkel, religionen, yder det samme og fortæller også historier, men han siger, at de er åbenbarede, og forlanger, at vi skal tro ham. I modsætning hertil er engagementet i litteraturen dobbelt: På den ene side tilbyder den en mulighed for identifikation og medliden. Man træder ind i et univers eller gør universet til en del af sig selv (cf. at man både sluger en bog og er opslugt af den). Og på den anden side er man ikke forpligtet af den. Den fremstiller jo en verden som kun er forestillet og derfor uden for praktisk rækkevidde. Netop dette er imidlertid litteraturens styrke.

Dobbeltheden af æstetisk distance og begærsmættet engagement giver nemlig mulighed for at forholde sig til noget fremmed, som var det en selv, og til sig selv som noget fremmed. Elskende har det på samme måde; men teksterne er sjældent så gode, og i øvrigt begynder de snart at betragte den andens tekst som apokryf.

Litteraturens manglende intimitet, dens teaterhvisken, åbner for en større. Tvetydigheden og usikkerheden angående hvem der taler, og hvem der tales til, betyder, at der bliver sagt mere og sagt noget andet end i den tale, hvormed 
man så at sige signerer en stiplet linie. Hvadenten alvorsmænd kan lide denne frivolitet eller ej. Selv litteraturhistorikere, der jo burde vide bedre, er oftest mest tilfredse, hvis de direkte kan knytte værkerne til digterens liv. Så ved de da, at han har lidt og elsket. For eksempel er dette tit gået ud over Horats, for hans piger var vist mest papirpiger. En af hans amerikanske oversættere og udgivere, George F. Whicher, skrev med ungdommelig brutalitet og uforstand et nydeligt digt om Horats' kærester. En strofe lyder således:

$\gg$ All were but syllabled air,

Fancies that flickeres and flew; Innocent Phidyle's prayer,

Chloe the fawn, and the few

Years that your Cinara knew,

Cinara, sweetest of flames!

Ah! Horace, I'm sorry for you! Alas! they were nothing but names «

(Whicher i Horace 1947:106)

Men selv om Whichers bedømmelse af Horats som udøvende erotiker sikkert er rigtig, så har han ganske uret i princippet. Digte rettet til kvinder, der skylder fantasien deres eksistens, siger fuldt så meget om kærlighedens væsen, som digte til damer af $k \emptyset \mathrm{d}$ og blod. Dels fordi fantasien udgør så stor en del af den, dels fordi den fiktive modtager gør det muligt at abstrahere og koncentrere og at sige ting, man vel ville vogte sig for at meddele sin virkelige elskede.

Den infantile fantasi, dagdrømmen og litteraturen er nære slægtninge, men alligevel meget forskellige. Slægtskabet betyder, at psykoanalysen kan tale med vægt om, hvad der er på færde i litteraturen, at den kan hjælpe os til at genkende vigtige elementer $i$ den og afdække det netværk af betydninger, de er en del af. Dens påstand om, at digtning er en særdeles driftsbestemt aktivitet, der giver digter og læser narcissistisk tilfredsstillelse, og som knytter forbindelserne til ubevidste billeder og ønsker, synes også uafviselig. En fejltagelse må man dog søge at undgå, når man anvender den til tolkning af litteraturen, nemlig at glemme, at digtning også er resultat af en bevidst, voksen og offentlig handling.

Privatteatret og verdensteatret er indbyrdes forbundne og fra begge fører gange til det ubevidste; men gangene mellem dem kan passeres i flere retninger: De historier Anna O. drømte, og som udtrykte hendes personlige krise og ubevidste fantasier, var formet efter Billedbog uden Billeder. 


\section{Noter}

1. Her gengivet fra Jørgen Dines Johansen 1986: 143.

2. Hvad angår fantasierne i disse ca. halvandet leveår er det vigtigt at være opmærksom på tre ting: For det første, at barnet ikke på dette tidspunkt kan rapportere dem verbalt. Dette betyder, at de nødvendigvis altid må foreligge som konstruktioner baseret på observationer af adfærd i den givne periode, på elementer i senere rapporterede fantasier og på almene hypoteser om psykens funktionsmåde og udvikling. For det andet, og dette gælder fantasier i almindelighed, at en verbal rapport er en ufuldstændig og ofte misvisende oversættelse af en psykisk tilstand og aktivitet, der ikke primært er verbal, men består af kropsfornemmelser, forestillinger $\mathrm{g}$ hallucinationer. $\mathrm{Og}$ for det tredie, at det sprog der anvendes til en beskrivelse af børns fantasier har to vanskeligheder, der kan være alvorlige fejlkilder. Dels det sprog, unge børn, der rapporterer deres fantasier, benytter, fordi ordenes begrebsmæssige og emotionelle værdi er forskellig fra det, de voksne forbinder med dem. Dels uligheden i barnepatientens og terapeutens sprogbeherskelse, der nødvendigvis gør terapeutens sprog til det overgribende og sammenhængsskabende. Dette gælder også i forholdet mellem en voksen analysand og anlytikeren; men det bliver særlig aktuelt i forhold til barnet, fordi dette heller ikke behersker dagligsproget.

3. Mekanismen er, at senere oplevelser eller fantasier reaktiverer erindringer eller fantasier fra en tidligere periode $\mathrm{i}$ barnets liv og tilbagegribende ændrer deres betydningsindhold og driftbesætning. Den tilbagegribende omtolkning af fortiden er selvfølgelig et helt alment fænomen i bevidst psykisk aktivitet, i affattelsen af en selvbiografi, i historieskrivningen og i fiktionen, f.eks. i kriminalromanen. Her har man f.eks. fra begyndelsen noteret, at butleren på mordaftenen havde en sort og en brun sok p§, men først til slut indser man dets betydning som et led i beviset for hans skyld. Forskellen til den tilbagegribende virkning i det ubevidste fantasiliv er imidlertid, at denne sidste er mere radikal, fordi der sker en fusion af elementer fra de to tidsmæssigt adskilte oplevelser. Her ville butleren altså efterlods blive tildelt to forskellige sokker, skønt han faktisk havde haft et par sorte på. I både ubevidste og bevidste fantasier rettes bager for smed (for en god fremstilling af dette aspekt af urfantasierne se Andkjær Olsen \& Køppe 1981: 398-400 og 442-47).

4. Begrebet ambivalens kan måske illustrere, hvad der er på spil her. Oftest dækker det den samtidige eksistens af to modsatte emotionelle holdninger til et objekt (e.g. kærlighed og had). Hvis man imidlertid forestiller sig, at ambivalensen ikke blot er emotionel, men intellektuel, således at objektet spaltes, og det i psyken konstitueres som to forskellige objekter, henholdsvis et godt og et ondt (spaltningen er ifølge kleinianerne et forsvar mod ambivalens). Og hvis man hertil føjer at grænsen subjekt-objekt ikke er stabilt representeret i det ubevidste, så får man en vis ide om det ubevidste fantasilivs ikke blot emotionelle, men også semantiske labilitet.

5. Disse aspekter af litteraturen har jeg behandlet mere udførligt i Dines Johansen 1992b. 


\section{Bibliografi}

Aristoteles (1958). Poetik (overs. Poul Helms) København (Nyt Nordisk Forlag Amold Busck).

Curtius, Emst Robert (1948). Europäische Literatur und lateinisches Mittelalter. Bern und München (Francke Verlag).

Eliot, T.S. (1957). On Poetry and Poets, (heri »The three Voices of Poetry«, 1953). London (Faber and Faber).

Erikson, Erik H. (1971). Barnet og samfundet. København (Hans Reitzel).

Freud, Sigmund (1980/[1895]). Udkast til en videnskabelig psykologi. København (Hans Reitzel).

- (1960/1900a). Drømmetydning I-II. København (Hans Reitzel).

- (1895/1905d). »Tre afhandlinger om seksualteori« $\mathrm{i}$ Afhandlinger om seksualteori. København (Hans Reitzel).

- (1983/1915e). »Det ubevidste«, i Metapsykologi I. København (Hans Reitzel).

- (1965/1916-17). Forelasninger til indføring i psykoanalysen. København (Hans Reitzel).

- (1985/1917c). »Om driftsomsætninger, især analerotikkens « i Afhandlinger om seksualteori. København (Hans Reitzel).

- (1947/1919e). »Ein Kind wird geschlagen« i Gesammelte Werke, Bd. XII. Frankfurt am Main (Fischer Verlag).

- (1966/1930a). Kulturens byrde. København (Hans Reitzel).

Freud, S und Breuer, J. (1970/1895). Studien über Hysterie. Frankfurt a. M. (Fischer Bücherei).

Gay, Peter (1988). Freud. A Life for Our Time. New York (W.W. Norton).

Goethe, J.W.v. (1963). Faust. Hamburg (Christian Wegner Verlag).

Horace (1947). Selected Poems (George F. Whicher, ed.). New York (Walter J. Black).

Isaacs, Susan (1948). »The Nature and Function of Phantasy«. I The International Journal of Psycho-Analysis, Vol. XXIX, Part II", pp. 73-97.

Jones, Ernest (1953-57). The Life and Work of Sigmund Freud I-III. New York (Basic Books).

Johansen, J. Dines (1986). Lille psykoanalytisk leksikon. København (Borgen).

- (1992b). "Desire: Representation and repetition in Literature«. Udkommer i Orbis Literarum 1992.

Laplanche, J. et Pontalis, J.-B. (1964), »Fantasme originaire, fantasmes des origines, origine du fantasme « i Les Temps modernes, no. 215, pp. 1833-68.

Olsen, O. Andkjær (1988). Ødipus-komplekset. København (Hans Reitzel).

Olsen, O. Andkjær og Køppe, S. (1981). Freuds psykoanalyse. København (Gyldendal).

Ovid (1943). Elskovskunsten (overs. Walt Rosenberg). København (Rasmus Navers Forlag). 
